\title{
Investigating Enterpreneurship Resilience and their Adaptive Capacities to Extreme Events: The Review of the Stabilisation and Association Agreement (Saa) Priorities
}

\author{
Ma Zamira Sinaj \\ Health Care Hospital, Vlora Region, Albania \\ Prof Ismail Zejneli \\ Dean of Low Faculty, SEEU University, Macedonia \\ Prof Assoc Dr. Alba Robert Dumi \\ Dean of Graduate School, “Ismail Qemali”Vlore University, Albania ,Management Department, \\ Ma Hava Mucollari \\ Economy Faculty Tirana University Albania
}

Doi:10.5901/ajis.2014.v3n3p358

\begin{abstract}
In this paper research we want to present the new low reforming in public administration system in Albania.Like any robust reform process, we face significant challenges across a spectrum of efforts. Designing country strategies was more time and labor intensive than originally anticipated, particularly because a large number of partners were engaged in the process to determine tough trade-offs. In the year ahead, we will continue to prioritize the development of country strategies and enable better coordination with our partners to reconcile competing priorities and focus on areas where we each have a comparative advantage. Regular political and economic dialogue between the EU and the country has continued through the SAA structures. The Stabilisation and Association Committee and Council met in March and April 2013 respectively. Meetings of six subcommittees and a meeting of the special group on public administration reform were held. Albania participates in the multilateral economic dialogue with the Commission and the EU Member States to prepare the country for participation in multilateral surveillance and economic policy coordination under the EU's Economic and Monetary Union Our effort to focus our assistance programs has been successful for the past two years either because we successfully exited from sustainable projects or because our programming was too minimal to have a true impact. As we look ahead, we must continue to make tough choices and use each country's strategy as the backbone for decision-making to ensure the greatest development impact.
\end{abstract}

Keywords: Law system, Legal Economic, Legal Institutions, Investigating, Emterpreneurship Resilience, Public needs, Decision Making

\section{Introduction}

Entrepreneurship has become a word of the day. Policymakers, economists, academics and even university students are talking about it. Seminars, conferences and workshops are being organized every year across the world which emphasized the importance of entrepreneurship to the economy of a country, society as well as individual development (Béchard and Toulouse 1998; Schaper and Volery 2004; Matlay and Westhead 2005). Entrepreneurship can be regarded as an "employment opportunity", helping people to get self-employed. (Kume A, Shahini B, Kume V)

\subsection{Theoretical framework and administrative Albanian reforms}

Administrative reform has been a particularly challenging area across most post-communist countries, especially in the Balkans region where, in addition to post-communist challenges, the states are also ravaged by political instability and not least civil unrest. Albania is a case in point. The administration is routinely staffed on the basis of politics rather than professional criteria, which has in part influenced the poor caliber of the whole administration. Politicization trends do not exempt the thin layer of more protected civil servants, whose career is regulated by specific laws. Hence, the country is a good case to assess whether EU enlargement conditionality has played a role to improve the record of reforms. 
The article, thus, analyses the role of EU conditionality in reforming state institutions, focusing on the specific case of civil service reforms in Albania. (Elbasani A, 2004). Albania needs to complement stability-oriented fiscal and monetary policies with structural reforms to ensure long-term sustainable economic growth. Albania will have to address the high levels of budget deficit and public debt and its short term bias. Moreover, it will need to improve fiscal predictability by reducing the recurrent overestimation of revenues and by collecting taxes more efficiently. Improving the business and investment environment is essential for diversifying the economy and boosting its long-term growth potential.

Today, entrepreneurship is regarded as one of the best economic development strategies to develop country's economic growth and sustain the country's competitiveness in facing the increasing trends of globalization (Schaper and Volery 2004; Venkatachalam and Waqif 2005). (Kume A, Shahini B, Kume V)

For most people, the popularity of entrepreneurship is largely due to the positive effects it has on many countries as a catalyst that creates wealth and the generation of job opportunities (Gurol and Atsan 2006). More specifically, entrepreneurship is a major engine driving many nations' economic growth, innovation and competitiveness. (Kume $A$, Shahini B, Kume V) At the same time, most studies have shown that there is a positive relationship between entrepreneurship and economic growth in terms of job creation, firm survival and technological change (Karanassios, Pazarskis et al. 2006). This could, inter alia, be achieved by reinforcing the rule of law, tackling corruption and addressing payment arrears, as well as developing infrastructure and enhancing human capital.
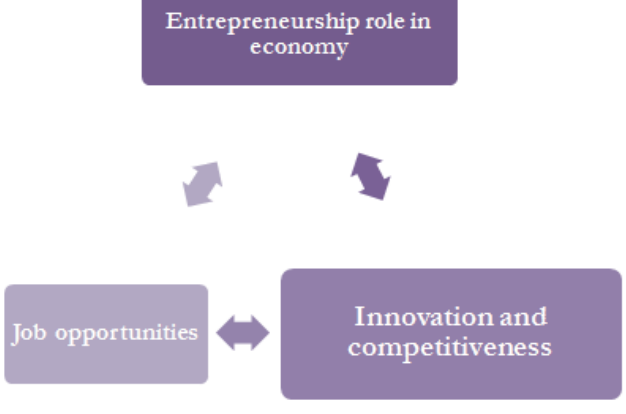

Source: Wealth and the generation of job opportunities, (Karanassios, Pazarskis et al.

The informal sector remains an important challenge. The Stabilizations and Association Agreement (SAA) continued to be overall smoothly implemented and Albania continued aligning its legislation to the requirements of the EU legislation in a number of areas, enhancing its ability to take on the obligations of membership. Improvements were made in areas such as public procurement, statistics, justice, freedom and security, and customs. Albania needs to make additional efforts to ensure effective enforcement of intellectual and industrial property rights, and pay particular attention to the energy sector, including the diversification of energy sources, the functioning of the electricity market, addressing concerns over network losses and low bill collection rates.

It also needs to address the issue of VAT refunds with determination, including as regards existing backlogs, and to reinforce environmental protection including through sustainable investments in the field of waste management and waste water. Most government officials, university faculty, and state-owned enterprise (SOE) administrators underwent training based on the communist political economy principles and ideologies. Consequently, modern business education was not available in Albania prior to 1992. (Kume A, Shahini B, Kume V)

Further efforts are needed in the fields of employment and social policy. The administrative capacity and professionalism of bodies charged with the implementation of the acquits needs to be strengthened and the independence of regulatory bodies safeguarded. In several acquits areas, in particular public procurement and financial control, it is important to enhance transparency and accountability. (Albanian Progress report 2013)

The industry has developed 'The Statement of Principles' to provide a powerful framework within which it can act alongside Government and other actors to address the issues that face property insurance. This guaranteed that the industry would continue to provide flood insurance provided that the Government ensured that appropriate flood defenses were developed. The current version expires in 2013 and we were advised that there is a significant possibility that it would not be renewed. 


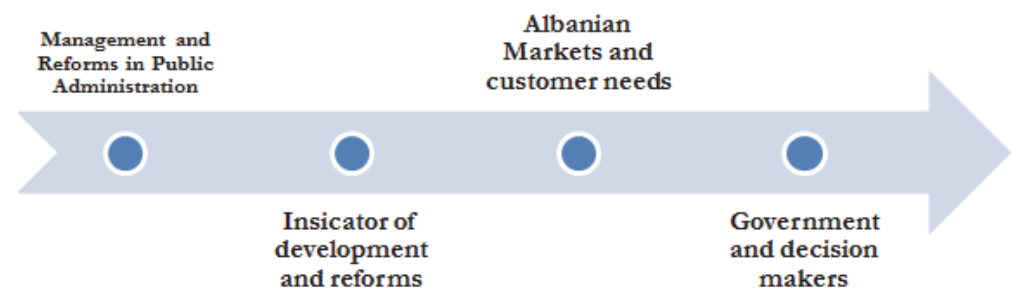

Source: Standardized norms and procedures for the management of institutions National Strategy for Development and Integration 2014-2020, internet link)

The most common view on the history of this agreement to date is that it has been successful in raising the profile of the issue on the agendas of both Government and decision makers in the industry and that benefits have resulted from it. However, it creates some significant market distortions that are suppressing innovation in the sector and that are also unfair to many customers. The multidisciplinary health reform focuses on improving governance and capacity building to ensure effective management of health services and institutions, health system financing, public access to quality health service and expansion of public protection services. . (National Strategy for Development and Integration 2014-2020, internet link)

\subsection{Public services and public areas, the principles of state}

An achievement to be noted is the placement of the family physician at the centre of the system and its functioning at three levels: primary, secondary and tertiary system. Other key developments are the continuous strengthening of the financial and managerial autonomy of Primary Health Care, the clear definition of the service package and treatment protocols, and increased infrastructure investment. Consequently, the average daily visits per family physician increased to 9.3 in 2011 compared to 5.7 before the autonomy was granted. The Health Insurance Institute has strengthened its role as the sole purchaser of health services through inclusion of the public hospital service in the health insurance scheme (January 2009) and increasing the number of reimbursable medicaments and contribution payers by strengthening the referral system and public information (National Strategy for Development and Integration 2014-2020, internet link)

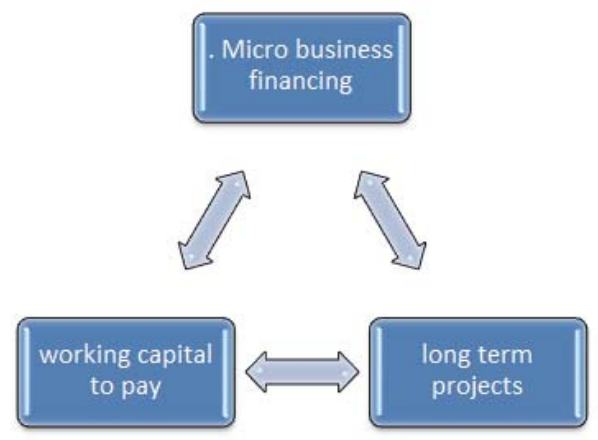

Source: States Agency for International Development (USAID) and the World Bank(WB) references

\subsection{Service resources and objective indicators}

Service resources are objective indicators of the level of resources available for the satisfaction of society's needs. For example, the number of physicians, dentists, acute-care hospital beds, and psychiatric care hospital beds are indicators of the level of health care resources. Square feet of parkland, picnic areas, tot lots, etc., are indicators of facilities for recreation needs. We were advised that some processes (e.g. additional 'compliance'-focused regulation) may be required to ensure that climate-related risks are addressed in future by less-developed operators when The Statement of 
Principles agreement with the Government on flood insurance expires in 2013. This will lead to a need further to develop underwriting competence in assessing and pricing flood risks, thereby stimulating an increase in capacity. Source: internet link, alexanderballet.com 2013

\section{Literature Review and Hypotheses}

At the same time, a structural reform occurred, which consisted in redefinition of core governing functions, through reformulating of missions, strategic objectives, organizational structures, functions and job descriptions. Within the frame of this reform, a new structure has been implemented in all ministries. Its basic assumption requires that in every ministry core functions should be grouped in four main pillars: $\bullet$ policy-making $\bullet$ regulation $\bullet$ services delivery $\bullet$ supporting services

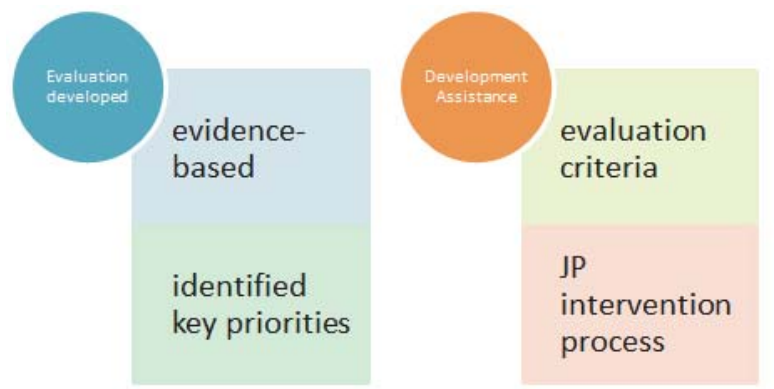

Source: Canter, L. W. 1985. Socio-economic Factors Used in Environmental Impact Studies. In Canter L.W., Impact of Growth: A Guide for Socio-economic Impact Assessment and Planning, pp. 328-394. Lewis Publishers: Chelsea,

The new residents and their associated activities will require a variety of services pro-vided by the areas public and private institutions. A social impact assessment must determine the quantity and variety of anticipated needs. The goods and services most commonly included in a social evaluation are open space and parks; cultural and recreation facilities; education; health care; special care for the elderly, the disabled, the indigent and preschool-age children; police and fire protection; and a variety of administrative support functions. The optimum amount of resources that would be required for the satisfaction of needs is based on either planning standards, which are guidelines established by professional organizations and government agencies, or service levels, which are observed national (or regional) average amounts of resources expended per capita or some unit of size.

Directories and similar functions have been grouped into each pillar. In the case of multifunctional structures, the priorities of functions decide and a general director leads the pillar, having so reduced the number of persons reporting to the general secretary of the ministry and grouping the functions under "a single roof". As a result the conflict between roles is avoided and a considerable amount of resources will be directed to policy-making strategy formulating processes. Focusing in a single process could also increase the capacity and specialization level of civil servants in a short-time period. (European Commission, "Albania Stabilization and Association Report 2002" Commission Staff Working Document (Brussels: European Commission, COM 2002 163), 6-7. Emphasis in original.20 Note that the 2003 EC Report emphasized the need for better capacities and leadership of the Department for European Integration (under the authority of the State Minister for European Integration). European Commission, "Albania Stabilization and Association Report 2003" Commission Staff Working Document(Brussels: European Commission, COM 2003 139), 19).

Challenges in this sector include: protect and improve public health through reachable and equal services for all; establish a qualitatively new health service; provide services with standards comparable to the EU countries, for all Albanian citizens; reform financial mechanisms and tools which ensure efficient financial coverage of the rising costs in the health system. (National Strategy for Development and Integration 2014-2020, internet link) The law abrogates existing legislation without providing the necessary transitory provisions until its implementing legislation enters into force; the government approved in September 2013 technical amendments to avoid this legal vacuum. Timely adoption of the secondary legislation compliant with the principles of the law and proper implementation is essential. The Law on General Administrative Procedures is still pending. (Commission working document, Albania Brusel 2014) 


\subsection{Assessing the current accessibility of public services}

- What is the present level of services in the community?

- What is the current distribution of services in the community (to social groups or to neighborhoods)?

- What are the anticipated needs and accessibility to services of the future population?

- Are there organizational or coordination problems currently being encountered by service organizations or agencies?

- May such problems be encountered in future service delivery? If so, what are they?

- What are the implications of future service and facility requirements and revenue sources on tax levels, net fiscal balance and service quality?

\subsection{Improve the quality of services through improved clinical and institutional management:}

The survey centered around two dimensions: entrepreneurial attitude, defined as the degree of positivity one feels towards the idea of becoming an entrepreneur; and motivation factors for growing their own business. To define the entrepreneurial profile of students four traits are used: locus of control, entrepreneurial self-efficacy, independence motive, innovation motive. Establish innovative organizational schemes and a new public-private partnership: 2. Reorganize the management and financing of public hospital and outpatient centre's aiming to increase their autonomy; 3. Determine the referral criteria between primary health care and specialized care in public and private health institutions, based on the service quality and the patient's right to choose the doctor. 4. Standardized norms and procedures for the management of institutions; 5.Structuring the institutional and national information systems in order to improve monitoring and management of institutions; 6.Creation of spaces required for the efficient use of income. (National Strategy for Development and Integration 2014-2020, internet link)

\section{Methodology and Research Goal}

This study aims both to improve operational practices and also to help identify a strategic agenda, which is an ideal focus in developing a strategic programmed for the sector. This has the potential to raise capacity in important areas. However, none of the operational units that we reviewed were part of this trial. In a more technical sense, the term is used to describe any form of insurance that provides protection against the costs of medical services. Source: State Children's Health Insurance Program, internet link, www.health\&benefits,dc 2013, Callon A.

This research is conducted by means of literature study and empirical analysis. For the literature review, we have consulted papers and researches relevant to entrepreneurial spirit of College students. Regarding empirical studies, data was gathered from a self-administered questionnaire conducted among Vlora University, Vlora Trade officee, SME in Vlora. The questionnaire was adapted from various sources and used as a means of data collection. It has two pages that consisted of seven sections: demographic and family background, future career planning and entrepreneurial inclination, locus of control, entrepreneurial self-efficacy, independence motive, and innovative motive. The scales used in the questionnaire was based on a 6-point Likert scale (with 1= strongly disagree, 2= disagree, 3= hardly agree, 4= partly agree, $5=$ =agree, $6=$ strongly agree) for each close-ended question.

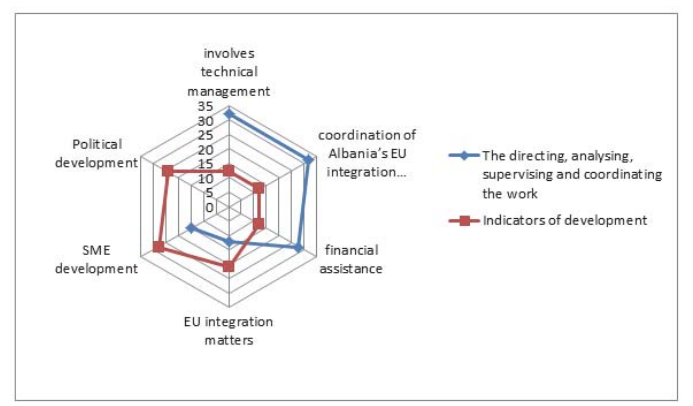

Source: European Commission, "Albania Stabilization and Association Report 2002" Commission Staff Working Document (Brussels: European Commission, COM 2002163 


\subsection{Data and methodology of study in this paper research}

When evaluations failed to meet the standard, the three most common concerns were: (1) evaluation teams received too many questions-especially questions that are too general and ill-defined-relative to the resources available for the evaluation, (2) the data collection and analysis methods were not appropriate to answer the evaluation questions, or (3) evaluation reports did not clearly demonstrate how evidence led to new findings and conclusions.

\subsection{Results and discussion and the respondents' profiles}

From the 59 usable questionnaires gathered, the majority of respondents were heavily females ( $N=37$ per cent). This scenario is understandable as female students comprise the majority of economic and business institutions in Albania.

As all of the respondents were studying at the undergraduate level, they were mostly aged between 20 to 25 years old ( $N=47,88$ per cent). Albanian managers expressed a healthy level of interest in entrepreneurship, with $35 \%$ of them have given serious thought to starting their own business. 5.8 per cent (30) of the interviewed are already self employers and 31 per cent of them are starting to do so. As should be evident from the preceding discussion, socio-economic impact assessment is a complex, yet important aspect of development impact analysis. The various changes in the social environment and social well-being of a community that result from development may be significant, yet they are often subtle and not easy to quantify. However, this does not mean that socio-economic impact assessment should not be considered an essential component of the development impact assessment process.

It is important to bear in mind that while certain individuals or community groups may be active and forthcoming with input into the planning process, other community groups (e.g., low income or minority groups) that may be equally or even disproportionately affected by the proposed development may be less vocal in expressing concerns and interests. In situations where traditionally disempowered groups may be impacted by a development, it is important to make a concerted effort to involve them in the social impact assessment process.

\section{Recommendations}

The analysis of the indicators of this paper research, suggests that the development of Albanian governmental structures in charge of the EU integration process may be divided into three phases which in fact reflectnot only the pace of Albania's integration efforts, but also the problems of the overall economic and political consolidation of an emerging democracy: In addition to the above described (macro-level) structures, the Albanian Governmentalso established specialized European Integration Units (EIU) in all line ministries to act asfocal points for EU-related assistance, reporting and monitoring. The Decision of the Councilof Ministers No. 179, dated 22/2/2006 outlines the responsibilities of these units, whichinvolve:a. internal coordination, ensuring direct links and cooperation with the MEI and otherline ministries regarding the obligations the country has assumed with the SAP; $b$. internal institutional coordination and coordination with the MEI and other lineministries regarding the approximation of legislation and reporting on legal actsadopting the acquis communautaire under TAIEX;c. internal institutional coordination regarding the preparation of reports on the processof European integration;d. monitoring and reporting within the ministry on EU integration matters;e. data sharing on the EU integration process between the ministry, the MEI and EIUs inother line ministries;f. assessing the performance of the institution in the process of European integration;propose functional mechanisms facilitating sectorial reforms, implementation of theSAA through approximation of Albanian legislation with acquis communautaire andstrengthening the administrative capacities;g. recommending priorities, planning of activities and human resources for the institutional support of the European integration proces.

\section{References}

Branch, K., \& Hooper, J. Thompson, and J. Creighton.1984. Guide to Social Assessment: A Framework for Assessing Social Change. Westview Press: Boulder.

Burdge, R.J. 1995. Community Guide to Social Impact Assessment, University of Illinois: Urbana.

Burdge, R.J., P. Fricke, K. Finsterbusch, W.R. Freudenberg, R. Gramling, A. Holden, L. Llewellyn, J.S. Petterson, J. Thompson, and G. Williams. 1995. Guidelines and Principles for Social Impact Assessment.

Environmental Impact Assessment Review. 15:11-43. Elsevier Science, Inc.: New York.

Canter, L. W. 1985. Socio-economic Factors Used in Environmental Impact Studies. In Canter L.W., Impact of Growth: A Guide for Socio-economic Impact Assessment and Planning, pp. 328-394. Lewis Publishers: Chelsea, Ml.

Chadwick, A. 1995. Socio-economic Impacts 2: Social Impacts. In Morris, P. And R. Therivel, Methods of Environmental Impact 
Assessment, pp. 29-49. University of British Columbia Press: Vancouver.

Chenoweth, R. 1999. Integrating information technologies for citizen-based land use decision-making. College of Agricultural and Life Sciences, University of Wisconsin.

Christensen, K. Social Impacts of Land Development: An Initial Approach for Estimating Impacts on Neighborhood Usages and Perceptions.

European Commission, "Albania Stabilization and Association Report 2002" Commission Staff Working Document (Brussels: European Commission, COM 2002 163), 6-7. Emphasis in original.20 Note that the 2003 EC Report emphasized the need for better capacities and leadership of the Department for

European Integration (under the authority of the State Minister for European Integration). European Commission, "Albania Stabilization and Association Report 2003" Commission Staff Working Document(Brussels: European Commission, COM 2003 139 ), 19.

Martín JJ. Crisis económica y sostenibilidad del Sistema Nacional de Salud, El Médico 2010; 1109:16-19. MOF , USAID Financial report 2011, pp 37-39

Sholdenn \& Maderings Health cure modelling ,Publish in American Journal, year 2011 pp 23,45

Theodorakis PN, Benton JI, Anderson JP, Glaros D, Trell E, Lionis C. A comparative study of two primary health care practices on the Greek-Albanian border: 51st European General Practice Research, 2008

Kume A, Kume V European Scientific Journal June 2013 edition vol.9, No.16 ISSN: 1857 - 7881 (Print) e - ISSN $1857-7431$

Tulgan, B. (1999a). GenXers' Free Agent Mindset has swept across the workforce. Generation X -The Workforce of the Future, 46, October. New Haven, CT: Rainmaker Thinking, Inc

Venkatachalam, V. B. and A. A. Waqif (2005). "Outlook on integrating entrepreneurship in management education in India." Decision 32(2): 57-71.

Wang, Aaiping, (2012) „Educational reform is the foundation of human Entrepreneurial characteristics amongst university students: Some insights for entrepreneurship education and training in Turkey." http://www.emeraldinsight.com/journals.htm 